\title{
Toxic metals in soil depths from selected abandoned sites: Occurrence, sources, ecological and human health risk
}

\author{
Onoriode Onos EMOYAN ${ }^{*},{ }_{\text {Godswill Okeoghene TESI },{ }^{2} \text { Efe OHWO },{ }^{1} \text { and Chijioke OLISAH }}{ }^{3}$ \\ ${ }^{I}$ Environmental Chemistry and Waste Management Research Group, Department of Chemistry, Delta State University, \\ P.M.B.1 Abraka, Nigeria \\ ${ }^{2}$ Department of Chemical Sciences, University of Africa, Toru-Orua, Bayelsa State, Nigeria \\ ${ }^{3}$ Department of Botany \& Institute for Coastal and Marine Research, Nelson Mandela University, Port Elizabeth 6031, \\ South Africa
}

\begin{abstract}
This study provides a comparative assessment of cadmium $(\mathrm{Cd})$, lead $(\mathrm{Pb})$, chromium $(\mathrm{Cr})$, nickel $(\mathrm{Ni})$, copper $(\mathrm{Cu})$, manganese $(\mathrm{Mn})$, zinc $(\mathrm{Zn})$, and iron $(\mathrm{Fe})$ pollution occurrence, sources, and exposure risk in soils from selected abandoned sites. The concentrations of metals were determined using atomic absorption spectrophotometry. The metals occurrence ranged from $0.02(\mathrm{Zn})$ to $16600 \mathrm{mg} \mathrm{kg}^{-1}(\mathrm{Fe})$ in the order of subsoil > topsoil with petroleum tank farm and fuel/gas service station exhibiting high metal loading. The sources of metals are anthropogenic and geologic. The hazard index values for infants' were higher than that of adults, and the inhalation risk for adults' was considerably higher than for infants' exposure. The ecological risk of $\mathrm{Cd}, \mathrm{Pb}, \mathrm{Cr}, \mathrm{Ni}$, and $\mathrm{Zn}$ falls in the contamination to pollution index. This study revealed the need for clean-up and restoration of abandoned site soils.
\end{abstract}

Keywords: land-use; toxic metals; anthropogenic; abandoned sites; exposure risk.

\section{Introduction}

Soil is a significant portion of the aquatic and terrestrial ecosystem that acts as a sink for priority pollutants and plays a vital function in the occurrence and fate of toxic metals [1]. Several studies depict the significant concentration of $\mathrm{Cd}, \mathrm{Pb}, \mathrm{Cr}, \mathrm{Ni}, \mathrm{Cu}, \mathrm{Mn}, \mathrm{Zn}$, and $\mathrm{Fe}$ in environmental matrices and food above target and intervention value and accumulate in fatty tissues. Depending on the concentrations and exposure duration, the occurrence of toxic metals in food above target and intervention values may cause optimum regulation dysfunction in living cells and exhibit human and ecological health hazards [2]. Naturally, the source of metals in soils is from parent rock materials, atmospheric-particle deposition, emissions from a volcanic eruption, oceans, lakes, and forests. However, exceeding the natural geochemical concentrations is the human-induced sources such as waste incineration, mining, emissions from fossil energy, leaded-fuel combustion engine, solid waste dump, metal and plastic scrap sites, lead-batteries, crude oil spills, use of fertilizers and pesticides, and industrial processing sites [3-5].

The study sites are selected abandoned sites characterized by the influence of different anthropogenic activities such as asphalt processing, petroleum tank farms, solid waste, auto-mechanic workshops, and fuel/gas service stations situated in Nigeria. Abandoned sites are known for spilled waste engine-oil and petroleum products, paint-metals deposits, metal and plastic scrap dump, pieces of equipment, machinery and trucks, equipment containing electrical appliances, fire resistance materials, PCBmetal oil and $\mathrm{Pb}-\mathrm{Cd}$ batteries, and domestic and commercial solid waste dump. These sites have been recognized as potential point and non-point sources of priority pollutants and have contributed significant concentrations of toxic metals to soils [6-9]. The study area aquifers have a high vulnerability to pollution because of the closeness of the water table to topsoil (< $10 \mathrm{~m} \mathrm{depth}$ ) and the unconsolidated nature of sediments [10].

In Nigeria, abandoned facilities are converted to residential, institutional, recreational, commercial, and agricultural catchments without proper site and soil clean-up actions. The non-compliance to standard guidelines for use in these catchments for other purposes may lead to considerable pollution load of the immediate and adjacent soils, surface, and groundwater aquifers [11]. Most environmental studies are connected with functional industrial sites and abandoned sites with single anthropogenic activity. Hence, data gaps showing the concentrations origin and associated risks of metals in soil depths from abandoned sites with different landuse. Over the years, several human and environmental health concerns about metals inputs in soils [12-18]. The concentrations of metals in abandoned sites are vital for evaluating the sources and human and environmental health hazards on the immediate and adjacent environment matrices. The concentration and associated health risks of $\mathrm{Cd}, \mathrm{Pb}, \mathrm{Cr}, \mathrm{Ni}, \mathrm{Cu}, \mathrm{Mn}, \mathrm{Zn}$, and $\mathrm{Fe}$, were determined in soil depths from selected abandoned sites of different land use. The results provided insights on the pollution concentrations ecological and human health risks from metals in soil depths from selected 
abandoned sites and can assist policy and decisionmakers to take action. This study represents a similar work environment, valuable in sustainable management of abandoned sites clean-up action for residential, commercial, recreational, institutional, and agricultural catchments.

\section{Experimental}

\subsection{Description of the study area}

The study sites are located in the Niger Delta, Nigeria, situated between latitudes $5^{\circ}-8^{\circ} \mathrm{E}$ and $3^{\circ}-6^{\circ} \mathrm{N}$. The land use operations were abandoned between 10-20 years ago and there is no evidence of natural restoration of soil. The weather and climatic conditions include the Oligocene-Pliestocene Benin Formation that constitutes the aquiferous zone, and annual rainfall above $200 \mathrm{~mm}$. The water table varies from 0.7 to $10 \mathrm{~m}$ depth (in some areas, shallow dug wells serve as primary water supply), an atmospheric temperature of 23 to $28{ }^{\circ} \mathrm{C}$, a subequatorial climate, high humidity, and long wet season. $[19,20]$. The sample codes are APS1 - asphalt processing site APS2 - asphalt processing site, PTF1 petroleum tank farm, PTF2 - petroleum tank farm, SWD1 - solid waste dump, SWD2 - solid waste dump, AMW1 - auto mechanic workshop, AMW2 - auto mechanic workshop, FSS1 - fuel service station, and FSS2 -fuel service station, Figure 1.

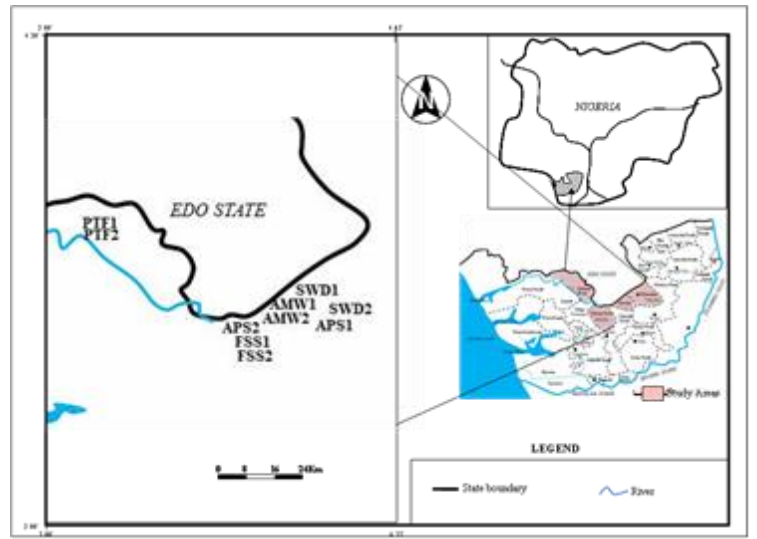

Figure 1. Map of Nigeria showing selected abandoned landuse sites (adapted in part from Emoyan et al. [37]).

\subsection{Sample collection}

After removal of debris from the topsoil, twenty samples were collected with a $2.5 \mathrm{~cm}$ diameter probe stainless steel auger at the top $(0-15 \mathrm{~cm})$ and subsoil $(15-30 \mathrm{~cm})$ from ten abandoned sites of different land use. A composite sample was derived from a quadruplet using standard quality control procedures. Glassware was soaked in $10 \% \mathrm{HNO}_{3}$ for 12 hours, washed twofold with deionized water, and dried in an oven.

\subsection{Sample digestion and analysis}

Upon removal of twigs and stones, the samples were airdried and sieved using a 2.0 mesh. The USEPA 3050B method was adopted for the digestion, thus $1 \mathrm{~g}$ of the sample was weighed into a $250 \mathrm{~mL}$ digestion tube, and addition of $15 \mathrm{~mL}$ of aqua regia $1: 3\left(\mathrm{HNO}_{3}: \mathrm{HCl}\right)$. In a heating plate, the mixture was heated at $120^{\circ} \mathrm{C}$ for 30 minutes. The digest was filtered using a Whatman No. 41 filter paper, diluted to $25 \mathrm{~mL}$ with $0.25 \mathrm{M} \mathrm{HNO}_{3}$, and stored in a pre-cleaned polyethylene container at $4{ }^{\circ} \mathrm{C}$ before analysis $[1,21]$. The concentrations of $\mathrm{Cd}, \mathrm{Pb}$, $\mathrm{Cr}, \mathrm{Ni}, \mathrm{Cu}, \mathrm{Mn}, \mathrm{Zn}$, and $\mathrm{Fe}$ in the digested samples were determined using a Varian SpectrAA200 flame atomic absorption spectrophotometry (Rikakikai Co. Ltd, Tokyo, Japan). The calibration line technique was adopted for the analysis, and the detection limit of the AAS was $0.001 \mathrm{mg} \mathrm{L}^{-1}$.

\subsection{Quality control and assurance}

The quality control and assurance were attained by adhering to the standard analytical practice of the manufacturer's recommendations in the preparation and analysis of samples. The sample containers and glassware were pre-cleaned with $10 \%$ nitric acid, and the reagents for metal digestion were of analytical grade. The validation of the analytical method was by the method blank and sample matrix, field blank, and spike recovery method. Samples were analyzed in triplicates.

\subsection{Human health risk assessment}

The human health risk was determined using the hazard index (HI) and the total cancer risk (TCR) models. The rationale behind the human health risk evaluation is exposure hence reported for the topsoil depth. The human health risk evaluation was by the assumption that the routes of exposure; are through ingestion, inhalation, and dermal (IID), [22, 23]. The definition and values of variables used in the non-cancer and cancer risks are presented in the supplementary materials (Table SM1 and SM2).

\subsection{Ecological risk evaluation}

2.6.1. Contamination and pollution index (CPI). The CPI was determined as stated by Emoyan et al. [1].

The reference target value of metals used is the Department of Petroleum Resources-Environmental standards and guidelines for the petroleum industry in Nigeria [24]. The definitions and values of variables used are presented supplementary material (Table SM3).

2.6.2. Index of geoaccumulation (Igeo). The Igeo quantity was applied to determine the contamination of metals by comparing current and pre-concentration levels $[1,25]$.

The crustal abundance values for metals were applied as the geochemical background levels. The value of 1.5 allows for natural fluctuations in the levels of a given metal in the soil matrix and very minimal anthropogenic impact. The Igeo classification is presented in the supplementary material (Table SM3).

2.6.3. Enrichment factor $(E F)$. The EF of metals was determined using the expression by Reimann and De Caritat [26] and Loska and Wiechula [27]. In this study, iron was selected as the reference metal for the EF evaluation because of its natural abundance relative to other metals. The crustal abundance values of metals were used as the background levels for the assessment of the EF. The categories of EF are shown in the supplemental material (SM3).

2.6.4. Ecological risk factor and potential ecological risk index. The ecological risk of metals was determined using expression by Turekian and Wedepohl [28] and Hakanson [1, 29]. 
The CAV of the metals were adopted as the background concentrations, and the quantitative definition of the ecological risk is presented in the supplementary material (Table SM4).

2.6.5. Soil quality guidelines (SQGs).The ecological effect range low (ERL), the biological effect range medium (ERM), the threshold effect level (TEL), and the probable effect level (PEL) are the SQGs applied for the determination of ecological risk [30, 31]. The values of ERL, ERM, TEL, and PEL used are presented in the supplementary materials (Table SM5).

\subsection{Data analysis}

The statistical package for the social sciences (SPSS) version 22 was applied for the evaluation of descriptive statistical. The ANOVA was used to determine the significant difference in the concentration of metals, while Pearson's correlation coefficient was used to determine if there is significant relationship among the metals.

\section{Results and discussion}

\subsection{Quality control and assurance}

The relative standard deviation ranged from 8 to $12 \%$. The average recoveries from the spiked sample matrix ranged from 96.7 to $101.4 \%$ of metals. The concentration of metals in the procedural blanks $(n=3)$ was below the limit of quantification, and the $\mathrm{r}^{2}$ for the calibration curves ranged from 0.9992 to 0.9999 . The relative standard deviation of triplicate analysis ranged from 8 to $12 \%$.

\subsection{Concentrations and compositional pattern}

The concentrations and summary statistics of the measured toxic metals are presented in Tables 1 and 2.

Table 1. Concentrations of metals in the top and subsoil from abandoned sites $\left(\mathrm{mg} \mathrm{kg}^{-1}\right)$

\begin{tabular}{|c|c|c|c|c|c|c|c|c|c|}
\hline Sites & Depth & Cd & $\mathbf{P b}$ & $\mathrm{Cr}$ & $\mathbf{N i}$ & $\mathbf{C u}$ & Mn & Zn & $\mathbf{F e}$ \\
\hline \multirow[t]{2}{*}{ APS1 } & Top soil & 2.98 & 0.25 & 7.53 & 0.28 & 23.1 & 13.6 & 0.02 & 28.6 \\
\hline & Sub soil & 8.33 & 0.75 & 8.03 & 126 & 12.7 & 51.1 & 1.24 & 24.9 \\
\hline \multirow[t]{2}{*}{ APS2 } & Top soil & 3.23 & 1.50 & 12.0 & 12.8 & 25.3 & 41.1 & 1.47 & 43.4 \\
\hline & Sub soil & 19.2 & 1.25 & 9.25 & 53.2 & 0.75 & 26.0 & 1.50 & 32.1 \\
\hline \multirow[t]{2}{*}{ PTF1 } & Top soil & 3.18 & 0.75 & 8.28 & 19.4 & 125 & 128 & 5.05 & 102 \\
\hline & Sub soil & 3.40 & 4.00 & 5.40 & 26.5 & 54.3 & 71.9 & 4.68 & 166 \\
\hline \multirow[t]{2}{*}{ PTFS2 } & Top soil & 3.08 & 0.50 & 7.91 & 9.84 & 74.1 & 70.8 & 2.54 & 65.3 \\
\hline & Sub soil & 5.87 & 2.38 & 6.72 & 76.3 & 33.5 & 61.5 & 1.37 & 95.5 \\
\hline \multirow[t]{2}{*}{ SWD1 } & Top soil & 3.16 & 1.00 & 9.95 & 11.3 & 49.7 & 56.0 & 2.00 & 83.7 \\
\hline & Sub soil & 12.5 & 1.81 & 7.98 & 64.7 & 17.1 & 43.8 & 1.44 & 63.8 \\
\hline \multirow[t]{2}{*}{ SWD2 } & Top soil & 3.17 & 0.88 & 9.12 & 15.4 & 87.3 & 92.0 & 3.53 & 92.8 \\
\hline & Sub soil & 7.97 & 2.91 & 6.69 & 45.6 & 35.7 & 57.8 & 1.40 & 115 \\
\hline \multirow[t]{2}{*}{ AMW1 } & Top soil & 3.12 & 0.69 & 8.51 & 12.6 & 80.7 & 81.4 & 3.03 & 79.1 \\
\hline & Sub soil & 6.92 & 2.64 & 6.70 & 60.9 & 34.6 & 59.7 & 1.40 & 105 \\
\hline \multirow[t]{2}{*}{ AMW2 } & Top soil & 3.14 & 0.84 & 9.23 & 12.0 & 65.2 & 68.7 & 2.52 & 81.4 \\
\hline & Sub soil & 9.72 & 2.23 & 7.34 & 62.8 & 25.9 & 51.7 & 1.42 & 84.5 \\
\hline \multirow[t]{2}{*}{ FSS1 } & Top soil & 3.15 & 0.86 & 9.17 & 13.7 & 76.3 & 80.3 & 3.02 & 87.1 \\
\hline & Sub soil & 8.85 & 2.57 & 7.02 & 54.2 & 30.8 & 54.8 & 1.40 & 99.7 \\
\hline \multirow[t]{2}{*}{ FSS2 } & Top soil & 3.14 & 0.77 & 8.84 & 13.1 & 78.5 & 80.9 & 3.03 & 83.1 \\
\hline & Sub soil & 7.88 & 2.60 & 6.86 & 57.6 & 32.7 & 57.2 & 1.41 & 102 \\
\hline
\end{tabular}

Table 2. Summary statistics of metals in the top and subsoil from abandoned sites $(n=10)$

\begin{tabular}{ccccccc|cccccc}
\hline \multicolumn{7}{c|}{ Topsoil } & \multicolumn{5}{c}{ Subsoil } \\
\hline & MEAN & SD & MEDIAN & MIN & MAX & \%CV & MEAN & SD & MEDIAN & MIN & MAX & \% CV \\
\hline $\mathrm{Cd}$ & 3.13 & 0.07 & 3.15 & 2.98 & 3.23 & 2.13 & 9.07 & 4.29 & 8.15 & 3.40 & 19.2 & 47.3 \\
$\mathrm{~Pb}$ & 0.81 & 0.32 & 0.81 & 0.25 & 1.50 & 40.4 & 2.31 & 0.90 & 2.47 & 0.75 & 4.00 & 38.9 \\
$\mathrm{Cr}$ & 9.05 & 1.25 & 8.98 & 7.53 & 12.0 & 13.8 & 7.20 & 1.04 & 6.94 & 5.40 & 9.25 & 14.4 \\
$\mathrm{Ni}$ & 12.0 & 4.87 & 12.7 & 0.28 & 19.4 & 40.5 & 62.8 & 25.8 & 59.3 & 26.5 & 126 & 41.1 \\
$\mathrm{Cu}$ & 68.5 & 30.1 & 75.2 & 23.1 & 125 & 44.0 & 27.8 & 14.7 & 31.7 & 0.75 & 54.3 & 53.0 \\
$\mathrm{Mn}$ & 71.3 & 30.6 & 75.6 & 13.6 & 128 & 42.9 & 53.5 & 12.2 & 56.0 & 26.0 & 71.9 & 22.7 \\
$\mathrm{Zn}$ & 2.62 & 1.32 & 2.78 & 0.02 & 5.05 & 50.4 & 1.73 & 1.04 & 1.41 & 1.24 & 4.68 & 60.2 \\
$\mathrm{Fe}$ & 7464 & 2269 & 8222 & 2860 & 10200 & 30.4 & 8889 & 4110 & 9756 & 2490 & 16600 & 46.2 \\
\hline
\end{tabular}

The concentration profile of $\mathrm{Cd}, \mathrm{Pb}, \mathrm{Cr}, \mathrm{Ni}, \mathrm{Cu}, \mathrm{Mn}$, $\mathrm{Zn}$, and Fe ranged from $0.02(\mathrm{Zn})$ to $16600 \mathrm{mg} \mathrm{kg}^{-1}(\mathrm{Fe})$, and the mean concentrations ranged from $0.81 \pm 0.32$ $\mathrm{mg} \mathrm{kg}-1(\mathrm{~Pb})$ to $8889 \pm 4110 \mathrm{mg} \mathrm{kg}^{-1}(\mathrm{Fe})$. The coefficients of variation are greater than 1 , and the median values are less sensitive to the skewness, suggesting a complex origin of metals in the abandoned land-use sites [32, 33]. The concentration of metals show considerable values between sample sites and varied significantly $(p<0.05)$. The concentrations depict an irregular trend in occurrence concerning soil depths and show pollution profile in the order of subsoil $>$ topsoil, and PTF > FSS > AMW > SWD > APS. The results depict the highest concentration of $\mathrm{Cd}, \mathrm{Pb}, \mathrm{Cr}$, $\mathrm{Ni}, \mathrm{Cu}, \mathrm{Mn}, \mathrm{Zn}$, and Fe at APS2, PTF1, PTF2, SWD1, SWD2, SWD2, PTF1, and AMW1, Table 1 and Figure 2. The high concentration of metals in petroleum tank farms and fuel service stations could be adduced to 
spilled waste engine-oil and leaded petroleum products, solid waste containing metallic materials, buried metallic components, $\mathrm{Cd}, \mathrm{Pb}$, and $\mathrm{Ni}$ containing paints, and coat-plating against corrosion in high-stress structures, metal scrap dump, machinery and trucks, equipment containing electrical appliances, fire resistance materials, $\mathrm{PCB}$-metal oil, and $\mathrm{Pb}-\mathrm{Cd}$ batteries $[1,34,35]$. The percentage concentrations of these metals in the top and subsoil is in the order of $\mathrm{Ni}<\mathrm{Pb}<$ $\mathrm{Cd}<\mathrm{Fe}<\mathrm{Cr}<\mathrm{Mn}<\mathrm{Zn}<\mathrm{Cu}$ and $\mathrm{Cu}<\mathrm{Zn}<\mathrm{Mn}<\mathrm{Cr}$ $<\mathrm{Fe}<\mathrm{Pb}<\mathrm{Cd}<\mathrm{Ni}$ respectively.

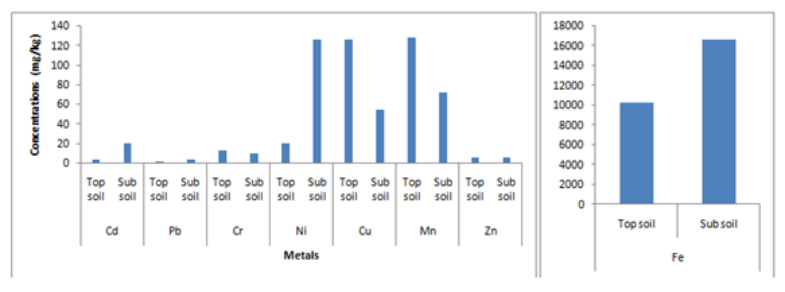

Figure 2. Peak concentrations of metals in the top and subsoil $\left(\mathrm{mg} \mathrm{kg}^{-1}\right)$

The concentration pattern of metals suggests a common trend in leaching and infiltration from the top to subsoil, input sources $[20,36,37]$. This is adduced to common; soil physicochemical characteristics, biochemical reactions within soil depths, reduced soils cohesion due to physical, biological, mechanical, and chemical factors, and vertical rather than the horizontal movement of metal mobility, thereby exposing bottom soil layers to contaminants [38]. In addition, the concentration of $\mathrm{Fe}$ could increase the rate of geochemical mobility and leaching of metals from active soil sites $[39,40]$. In this study, $100 \%$ (Cd), $40 \%$ $(\mathrm{Ni})$, and $40 \%(\mathrm{Cu})$ values surpassed the maximum target value prescribed by DPR respectively (DPREGAPSIN, 2002). The concentrations of metals were relatively comparable to the concentrations in some studies from different anthropogenic impacted soils [1, $4,8,9,14,15,17,18,41-43]$.

Upon exposure, the observed $\mathrm{Pb}$ and $\mathrm{Ni}$ concentration may cause oxidative stress toxicity in living cells, microorganisms could suffer severe growth decline, suppress the overall growth of plants, reduce biomass, and catalyze huge imbalance in ion uptake by plants, and considerable metabolic alteration in photosynthetic ability in plants around the abandoned sites upon reuse for agricultural production. Also the influence of biomagnifications, water-soluble $\mathrm{Zn}$ can contaminate groundwater aquifer and the food chain; disrupt the physiological activity of earthworms and microorganisms in soils, thus retarding the regular breakdown of organic materials in the soil around the abandoned land-use sites [44-47]. In addition, microbial metabolisms could be limited by $\mathrm{C}$ and $\mathrm{P}$ resulting from $\mathrm{Cd}, \mathrm{Pb}$, and $\mathrm{Zn}$ pollution, and the caused stress considerably increased the microbial $\mathrm{C}$ limitation, hence microorganisms may increase the energy value in metabolism to resist metal tension and thus activate $\mathrm{C}$ release [48].

Due to infiltration, diffuse and direct migration, and accumulation of pollutants, the unconsolidated nature of the sediments, abundant thick sandy sequence, and shallow water table of the study area, the observed concentration of metals may contaminate adjacent soils, ground and surface water resources in the monsoon season [10]. However, this scenario may be determined by the water chemistry and water-rock interaction [20, $25,49,50]$. In addition, based on the concentrations, duration, and routes of exposure, the observed $\mathrm{Cd}, \mathrm{Pb}$, $\mathrm{Cr}, \mathrm{Ni}, \mathrm{Cu} \mathrm{Mn}$, and $\mathrm{Zn}$ concentrations depict significant ecological and human health challenges if accumulated concentrations surpass the allowable standard values [51]. However, these health hazards may be negligible if the metals present are restricted to the insoluble, inert, and immobile species such as $\mathrm{Pb}\left(\mathrm{PO}_{4}\right)_{3} \mathrm{Cl}, \mathrm{PbS}, \mathrm{PbSO}_{4}$, $\mathrm{Pb}_{3}\left(\mathrm{PO}_{4}\right)_{2}, \mathrm{Ni}_{2} \mathrm{O}_{3}, \mathrm{NiO}_{2}, \mathrm{Cr}(\mathrm{OH})_{3}$ [52-54]. The reuse of the abandoned sites for agricultural, residential, recreational, institutional, and commercial purposes may increase the potential for onsite occupational exposure risk.

\subsection{Pearson correlation coefficients and ANOVA}

The Pearson correlation matrix of metals in soil, (Table 3) shows a moderate correlation between $\mathrm{Cd}$ and $\mathrm{Mn}$, $\mathrm{Zn}, \mathrm{Fe} ; \mathrm{Pb}$ and $\mathrm{Ni}$, a good correlation between $\mathrm{Cd}$ and $\mathrm{Cr}, \mathrm{Ni} ; \mathrm{Ni}$ and $\mathrm{Mn}, \mathrm{Fe} ; \mathrm{Cu}$ and $\mathrm{Fe}, \mathrm{Zn}$, strong correlations between $\mathrm{Cd}$ and $\mathrm{Pb}, \mathrm{Cr} ; \mathrm{Pb}, \mathrm{Cr} ; \mathrm{Cu}$ and $\mathrm{Mn}$, $\mathrm{Zn}, \mathrm{Fe} ; \mathrm{Mn}$ and Fe; $\mathrm{Zn}$ and Fe. The marked variability in correlation among metals suggests a common trend in their physicochemical properties and reactivity in soils [55]. The correlationbetween metals could be adduced to common sources attributed to the presence of metal equipment; trucks containing $\mathrm{Pb}-\mathrm{Cd}$ batteries, metallic materials, metal scrap, and asphalt dump in the abandoned sites [56, 57]. The values of t-test and ANOVA depict no significant difference between the total concentration of metals and soil depths (Table SM7 and SM8).

Table 3. Pearson's correlation coefficient of metals in top and subsoil from abandoned sites

\begin{tabular}{lcccccccc}
\hline & $\mathbf{C d}$ & $\mathbf{P b}$ & $\mathbf{C r}$ & $\mathbf{N i}$ & $\mathbf{C u}$ & $\mathbf{M n}$ & $\mathbf{Z n}$ & $\mathbf{F e}$ \\
\hline $\mathbf{T}$ Topsoil & & & & & & & & \\
$\mathrm{Cd}$ & 1.00 & & & & & & & \\
$\mathrm{~Pb}$ & $0.90^{*}$ & 1.00 & & & & & & \\
$\mathrm{Cr}$ & $0.76^{*}$ & $0.97^{*}$ & 1.00 & & & & & \\
$\mathrm{Ni}$ & $0.84^{*}$ & $0.52^{* *}$ & 0.29 & 1.00 & & & & \\
$\mathrm{Cu}$ & 0.30 & -0.15 & -0.39 & $0.77^{*}$ & 1.00 & & \\
$\mathrm{Mn}$ & $0.50^{* *}$ & 0.06 & -0.19 & $0.88^{*}$ & $0.98^{*}$ & 1.00 & & \\
$\mathrm{Zn}$ & $0.54^{* *}$ & 0.11 & -0.13 & $0.91^{*}$ & $0.96^{*}$ & $1.00^{*}$ & 1.00 & \\
$\mathrm{Fe}$ & $0.51^{* *}$ & 0.13 & -0.10 & $0.83^{*}$ & $0.86^{*}$ & $0.90^{*}$ & $0.90^{*}$ & \\
$\mathrm{Sub}$ soil & & & & & & & &
\end{tabular}




\begin{tabular}{lcccccccc}
\hline & $\mathbf{C d}$ & $\mathbf{P b}$ & $\mathbf{C r}$ & $\mathbf{N i}$ & $\mathbf{C u}$ & $\mathbf{M n}$ & $\mathbf{Z n}$ & $\mathbf{F e}$ \\
\hline $\mathrm{Cr}$ & $0.92^{*}$ & -0.90 & 1.00 & & & & & \\
$\mathrm{Ni}$ & 0.06 & -0.79 & 0.24 & 1.00 & & & & \\
$\mathrm{Cu}$ & -0.88 & $0.94^{*}$ & -1.00 & -0.53 & 1.00 & & & \\
$\mathrm{Mn}$ & -0.99 & $0.77^{*}$ & -0.97 & -0.21 & $0.94^{*}$ & 1.00 & & \\
$\mathrm{Zn}$ & -0.43 & $0.76^{*}$ & -0.60 & -0.54 & $0.72^{*}$ & $0.50^{* *}$ & 1.00 & 1.00 \\
$\mathrm{Fe}$ & -0.73 & 1.00 & -0.94 & -0.72 & $0.97^{*}$ & $0.82^{*}$ & $0.76^{*}$ & \\
\hline
\end{tabular}

\subsection{Human health risk assessment}

Cancer and non-carcinogenic risk assessment were based on exposure; hence, the hazard index and total cancer risks were reported for the topsoil.

3.4.1. Non-carcinogenic risk. The hazard index for infants' and adults' exposure to metals (Table SM9 and Figure 3), depicts that the hazard quotient for human exposures to the metals is in the order of HQIng > HQDerm > HQInh. The hazard index and hazard quotient values for the exposure routes suggest no adverse non-carcinogenic health risk for human exposure to metals in soils around the abandoned sites. The hazard index values for infants' exposure were greater than for adults' exposure; this is attributed to exposure duration and smaller body load of infants' to soil and/or dust particles at play hours [58].

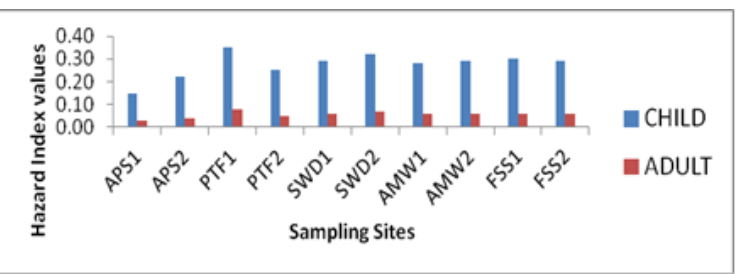

Figure 3. Hazard index of metals for infants and adults in topsoil. (The HI value $<1$ and $>1$ depicts no adverse non-

carcinogenic risk and adverse non-carcinogenic risk respectively)

3.4.2. Total cancer risk. The carcinogenic risk evaluated as a total cancer risk for human exposures to metals in the topsoil (Table SM10 and Figure 4), ranged from 9.38 $\times 10^{-6}$ to $1.54 \times 10^{-5}$ for the infants' exposure, and 3.98 $\times 10^{-6}$ to $6.84 \times 10^{-6}$ for adults' exposure, suggesting that soils around the abandoned land-use sites are within acceptable safe limits. The total cancer risk values for infants and adults in the exposure pathways are in the order of HQDerm < HQInh < HQIng. The risk through inhalation exposure for infants was considerably less than for adults' exposure, suggesting a longer exposure duration for adults [59-61].

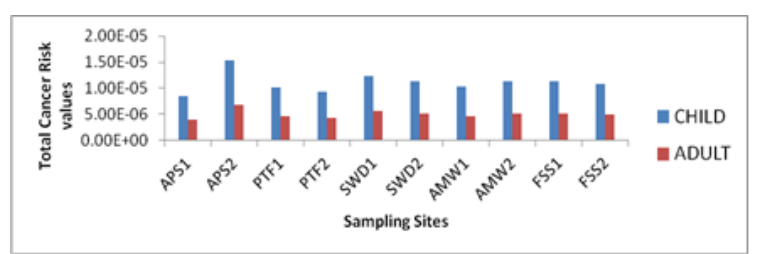

Figure 4. The total cancer risk of metals for infants and adults in topsoil. (The TCR value $<1 \times 10^{-6}$ and $>1 \times 10^{-6}$ depict no cancer risk and cancer risk respectively)

\subsection{Ecological risk assessment}

3.5.1. Contamination/pollution index. The results of contamination/pollution index and MPI (SM11 and Figure 5) show that CPI values for Cd were greater than 1 , depicting pollution range. The CPI values for $\mathrm{Pb} \mathrm{Cr}$ and $\mathrm{Zn}$ were less than 1 and falls in the contamination range. The contamination/pollution index values for $\mathrm{Ni}$ and $\mathrm{Zn}$ were $45 \%$ greater than 1 and falls in the contamination range. The multiple pollution index values ranged from 3.73 to 25.5 with considerable contribution from $\mathrm{Cd}$.

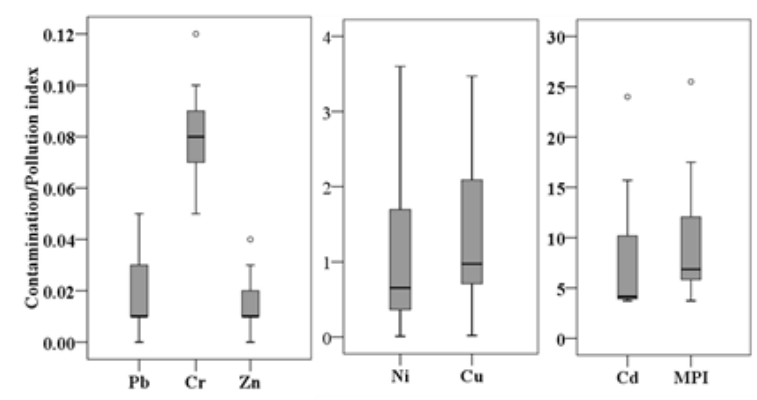

Figure 5. The contamination/pollution index values for $\mathrm{Cd}$ were greater than 1 , for $\mathrm{Pb}, \mathrm{Cr}$ and $\mathrm{Zn}$ were less than 1 , and for $\mathrm{Ni}$ and $\mathrm{Zn}$ were $45 \%$ greater than 1 .

3.5.2. Enrichment factors. The enrichment factors value of metals (SM11 and Figure 6) depict that Cd values were greater than 10 and ranged from 32 to 937 , and $96 \%$ of the samples fall in the extremely high enrichment category. The enrichment factors of $\mathrm{Cd}$ suggest non-crustal anthropogenic input as a source of $\mathrm{Cd}$. The enrichment factors values for $\mathrm{Pb}, \mathrm{Cr}, \mathrm{Mn}$ and $\mathrm{Zn}$ ranged from 0.2 to $0.8,0.17$ to $1.68,0.24$ to 0.69 and 0.06 to 0.25 respectively. The enrichment factors values of $\mathrm{Pb}, \mathrm{Cr}, \mathrm{Mn}$, and $\mathrm{Zn}$ suggest crustal source and deficiency to minimal enrichment category. The enrichment factor for $\mathrm{Ni}$ and $\mathrm{Cu}$ ranged from 0.07 to 34.98 and 0.24 to 12.80 respectively. This depicts extremely high enrichment, very high enrichment, significant enrichment, moderate enrichment, and deficiency to minimal enrichment categories. The enrichment factors of $\mathrm{Ni}$ and $\mathrm{Cu}$ were less than 10 in $90 \%$ and $85 \%$ of the samples indicating a crustal source.

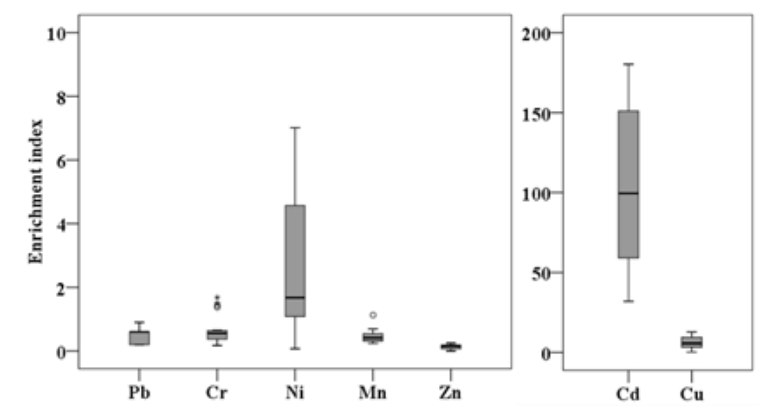

Figure 6. The enrichment factors of $\mathrm{Cd}$ and $\mathrm{Pb}, \mathrm{Cr}, \mathrm{Mn}$, and $\mathrm{Zn}$ suggest non-crustal anthropogenic and crustal source and deficiency to minimal enrichment category respectively. The enrichment factor for $\mathrm{Ni}$ and $\mathrm{Cu}$ falls in minimal to extremely high enrichment category

3.5.3. Geoaccumulation index (Igeo). The Igeo values for metals (SM12 and Fig. 7) were less than 0 except 
$\mathrm{Cd}$ and $\mathrm{Cu}$, depicting class 1 category for $\mathrm{Pb}, \mathrm{Cr}, \mathrm{Ni}$, $\mathrm{Mn}$, and $\mathrm{Zn}$. However, in the Igeo in $30 \%$ of the samples, $\mathrm{Cu}$ falls in the moderately polluted class. The Igeo values for $\mathrm{Cd}$ fall in the severe contamination to the slight pollution class. The Igeo values indicate that soils around the abandoned sites are polluted with $\mathrm{Cd}$ and $\mathrm{Cu}$, and their occurrence depicts geologic and anthropogenic sources.

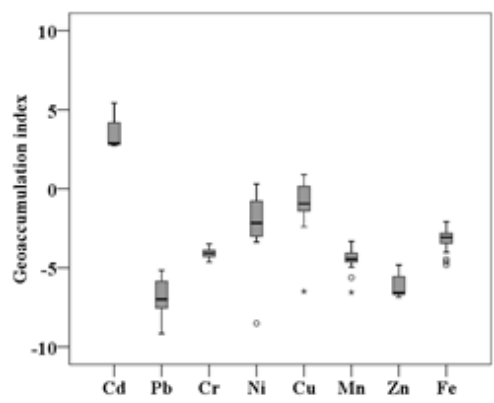

Figure 7. The geoaccumulation index of metals falls in class 1 to severe pollution category

3.5.4. Contamination factor (Cf) and degree of contamination. The contamination factor of metals ranged from 9.93 to $64,0.01$ to $0.15,0.06$ to $0.13,0.14$ to $1.85,0.02$ to $2.78,0.02$ to 0.11 , and 0.01 to 0.05 respectively, (Table SM13). The average contamination factor is in the order of: $\mathrm{Cd}>\mathrm{Cu}>\mathrm{Ni}>\mathrm{Pb}>\mathrm{Cr}>\mathrm{Mn}$ $>\mathrm{Zn}$, suggesting that $\mathrm{Cd}$ contributed a considerable amount to metals contamination of the abandoned sites. The degree of contamination ranged from 10.56 to 65.01, indicating considerable to high contamination index.

3.5.5. Ecological risk factor and potential ecological risk index. The ecological risk factor of metals ranged from 298 to $1920,0.06$ to $1,0.12$ to $0.27,0.02$ to 9.26 , 0.08 to $13.89,0.02$ to 0.15 , and 0.01 to 0.04 respectively, (Table 4). The ecological risk factor of $\mathrm{Cd}$ and $\mathrm{Pb}, \mathrm{Cr}$, $\mathrm{Ni}, \mathrm{Cu}, \mathrm{Mn}$, and $\mathrm{Zn}$, falls in the low-risk and the very high-risk categories respectively. The average ecological risk factor is in the order of: $\mathrm{Cd}>\mathrm{Cu}>\mathrm{Ni}>$ $\mathrm{Pb}>\mathrm{Cr}>\mathrm{Mn}>\mathrm{Zn}$. The potential ecological risk index ranged from 301 to 1925 with Cd showing a significant risk index, and the average ecological risk index depicts very high ecological risk for the abandoned sites.

Table 4. Ecological risk factor, potential ecological risk index and pollution degree of metals in top and subsoil from abandoned sites

\begin{tabular}{|c|c|c|c|c|c|c|c|c|c|c|}
\hline \multirow[b]{2}{*}{ Site } & \multirow[b]{2}{*}{ Depth } & \multicolumn{7}{|c|}{ Ecological Risk Factor $\left(\mathbf{E}_{\mathbf{r}}^{\mathbf{i}}\right)$} & \multirow{2}{*}{$\begin{array}{l}\text { Potential Risk } \\
\text { Index (RI) }\end{array}$} & \multirow[t]{2}{*}{ Risk Level } \\
\hline & & Cd & $\mathbf{P b}$ & $\mathrm{Cr}$ & $\mathbf{N i}$ & $\mathrm{Cu}$ & Mn & Zn & & \\
\hline \multirow[t]{2}{*}{ APS1 } & Top soil & 298 & 0.06 & 0.17 & 0.02 & 2.57 & 0.02 & 0.00 & 301 & Very high \\
\hline & Sub soil & 833 & 0.19 & 0.18 & 9.26 & 1.41 & 0.06 & 0.01 & 844 & Very high \\
\hline \multirow[t]{2}{*}{ APS2 } & Top soil & 323 & 0.38 & 0.27 & 0.94 & 2.81 & 0.05 & 0.02 & 327 & Very high \\
\hline & Sub soil & 1920 & 0.31 & 0.21 & 3.91 & 0.08 & 0.03 & 0.02 & 1925 & Very high \\
\hline \multirow[t]{2}{*}{ PTF1 } & Top soil & 318 & 0.19 & 0.18 & 1.43 & 13.89 & 0.15 & 0.05 & 334 & Very high \\
\hline & Sub soil & 340 & 1.00 & 0.12 & 1.95 & 6.03 & 0.08 & 0.05 & 349 & Very high \\
\hline \multirow[t]{2}{*}{ PTFS2 } & Top soil & 308 & 0.13 & 0.18 & 0.72 & 8.23 & 0.08 & 0.03 & 317 & Very high \\
\hline & Sub soil & 587 & 0.59 & 0.15 & 5.61 & 3.72 & 0.07 & 0.01 & 597 & Very high \\
\hline \multirow[t]{2}{*}{ SWD1 } & Top soil & 316 & 0.25 & 0.22 & 0.83 & 5.52 & 0.07 & 0.02 & 322 & Very high \\
\hline & Sub soil & 1253 & 0.45 & 0.18 & 4.76 & 1.90 & 0.05 & 0.02 & 1261 & Very high \\
\hline \multirow[t]{2}{*}{ SWD2 } & Top soil & 317 & 0.22 & 0.20 & 1.13 & 9.70 & 0.11 & 0.04 & 328 & Very high \\
\hline & Sub soil & 797 & 0.73 & 0.15 & 3.35 & 3.97 & 0.07 & 0.01 & 805 & Very high \\
\hline \multirow[t]{2}{*}{ AMW1 } & Top soil & 312 & 0.17 & 0.19 & 0.93 & 8.97 & 0.10 & 0.03 & 323 & Very high \\
\hline & Sub soil & 692 & 0.66 & 0.15 & 4.48 & 3.85 & 0.07 & 0.01 & 701 & Very high \\
\hline \multirow[t]{2}{*}{ AMW2 } & Top soil & 314 & 0.21 & 0.21 & 0.88 & 7.24 & 0.08 & 0.03 & 323 & Very high \\
\hline & Sub soil & 972 & 0.56 & 0.16 & 4.62 & 2.87 & 0.06 & 0.01 & 981 & Very high \\
\hline \multirow[t]{2}{*}{ FSS1 } & Top soil & 315 & 0.21 & 0.20 & 1.00 & 8.47 & 0.09 & 0.03 & 325 & Very high \\
\hline & Sub soil & 885 & 0.64 & 0.16 & 3.99 & 3.42 & 0.06 & 0.01 & 893 & Very high \\
\hline \multirow[t]{2}{*}{ FSS2 } & Top soil & 314 & 0.19 & 0.20 & 0.97 & 8.72 & 0.10 & 0.03 & 324 & Very high \\
\hline & Sub soil & 788 & 0.65 & 0.15 & 4.23 & 3.63 & 0.07 & 0.01 & 797 & Very high \\
\hline
\end{tabular}

3.5.6. Comparison of the metals with $S Q G$. The ecological risk was evaluated by comparing observed heavy metals concentrations with SQGs values (Table SM5). The results show that 0.0 to $100 \%$ and 0.0 to $100 \%$ of the samples have metal values less than their TEL and ERL values respectively. Also, 0.0 to $85 \%$ and 0.0 to $85 \%$ of the samples have concentrations of heavy metals between TEL-PEL and ERL-ERM respectively. However, 0.0 to $40 \%$ and 0.0 to $45 \%$ of the samples have metals concentrations greater than their respective ERM and PEL respectively. This suggests a low ecological risk to biota on exposure to the soil around the abandoned sites.

\subsection{Source apportionment}

3.6.1. Principal component analysis. In this study, two PCA component factors were identified in the top and subsoil, (Table 5). The topsoil depicts high loading of $\mathrm{Ni}, \mathrm{Cu}, \mathrm{Mn}, \mathrm{Zn}$, and $\mathrm{Fe}$, and $\mathrm{Cd}, \mathrm{Pb}$, and $\mathrm{Cr}$ in factors 1 and 2 respectively, and Factor 1 accounted for $60.627 \%$ of the total variation. The subsoil shows high loading of $\mathrm{Cu}$ and $\mathrm{Mn}$, and $\mathrm{Pb}, \mathrm{Zn}$, and Fein factors 1 and 2 respectively, and Factor 1 accounted for $55.207 \%$ of the total variation. The values of the principal component analysis of metals are attributed to common physicochemical properties, origin, and mobility potential in the soil profiles [62].

Table 5. PCA of metals in top and subsoil from abandoned sites

\begin{tabular}{|l|c|c|c|c|}
\hline \multirow{2}{*}{} & \multicolumn{2}{|c|}{ Topsoil } & \multicolumn{2}{c|}{ Subsoil } \\
\cline { 2 - 5 } & \multicolumn{2}{|c|}{ Component } & \multicolumn{2}{c|}{ Component } \\
\cline { 2 - 5 } & 1 & 2 & 1 & 2 \\
\hline $\mathrm{Cd}$ & 0.466 & $\mathbf{0 . 8 8 4}$ & -0.997 & -0.075 \\
\hline $\mathrm{Pb}$ & 0.036 & $\mathbf{0 . 9 9 9}$ & 0.608 & $\mathbf{0 . 7 8 3}$ \\
\hline
\end{tabular}




\begin{tabular}{|l|c|c|c|c|}
\hline \multirow{2}{*}{} & \multicolumn{2}{|c|}{ Topsoil } & \multicolumn{2}{c|}{ Subsoil } \\
\cline { 2 - 5 } & \multicolumn{2}{|c|}{ Component } & \multicolumn{2}{c|}{ Component } \\
\cline { 2 - 5 } & 1 & 2 & 1 & 2 \\
\hline $\mathrm{Cr}$ & -0.209 & $\mathbf{0 . 9 7 8}$ & -0.891 & -0.450 \\
\hline $\mathrm{Ni}$ & $\mathbf{0 . 8 6 9}$ & 0.489 & 0.011 & -0.981 \\
\hline $\mathrm{Cu}$ & $\mathbf{0 . 9 7 9}$ & -0.187 & $\mathbf{0 . 8 4 4}$ & 0.532 \\
\hline $\mathrm{Mn}$ & $\mathbf{0 . 9 9 6}$ & 0.026 & $\mathbf{0 . 9 7 5}$ & 0.221 \\
\hline $\mathrm{Zn}$ & $\mathbf{0 . 9 9 3}$ & 0.077 & 0.361 & $\mathbf{0 . 6 8 2}$ \\
\hline $\mathrm{Fe}$ & $\mathbf{0 . 9 3 1}$ & 0.094 & 0.682 & $\mathbf{0 . 7 2 3}$ \\
\hline Variance \% & $\mathbf{6 0 . 2 6 7}$ & $\mathbf{3 7 . 8 1 6}$ & $\mathbf{5 5 . 2 0 7}$ & $\mathbf{3 8 . 7 8 2}$ \\
\hline Cumm Var. \% & $\mathbf{6 0 . 2 6 7}$ & $\mathbf{9 8 . 0 8 3}$ & $\mathbf{5 5 . 2 0 7}$ & $\mathbf{9 3 . 9 8 9}$ \\
\hline
\end{tabular}

3.6.2. Cluster analysis. The homogeneity and relationship between metals and the samples were determined using cluster analysis (Figure 8 and 9). The dendrogram between metals depicts that $\mathrm{Cd}, \mathrm{Pb}, \mathrm{Cr}, \mathrm{Ni}$, $\mathrm{Cu}, \mathrm{Mn}$, and $\mathrm{Zn}$ formed a cluster, and $\mathrm{Fe}$ is an independent entropy member. The dendrogram between the samples shows that four clusters were formed with a linkage at FSS1A, PTF2A, FSS1B, and APS1B, with $\mathrm{PTF} 1 \mathrm{~B}$, an independent entropy member. The proneness of the metals and samples to a cluster is an attribute of common physicochemical properties, origin, degradation pattern, and mobility potential in the soil matrix [58, 63].

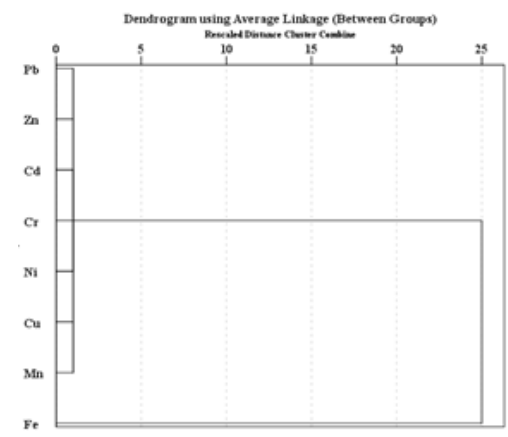

Figure 8. The dendrogram of $\mathrm{Cd}, \mathrm{Pb}, \mathrm{Cr}, \mathrm{Ni}, \mathrm{Cu}, \mathrm{Mn}$, and $\mathrm{Zn}$ formed a cluster, and $\mathrm{Fe}$ is an independent entropy member

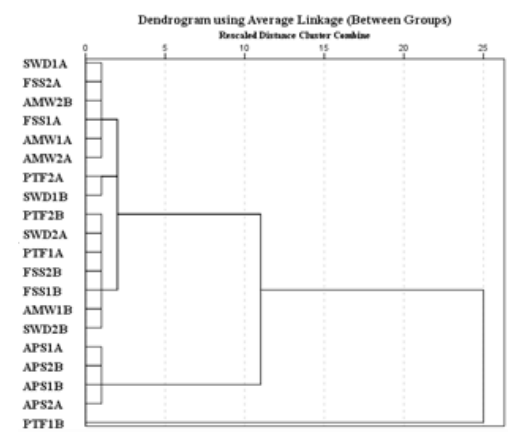

Figure 9. The sample site dendrogram formed four clusters with a linkage at FSS1A, PTF2A, FSS1B, and APS1B, with $\mathrm{PTF} 1 \mathrm{~B}$, an independent entropy member

\section{Conclusions}

The concentrations, sources, and human and ecological health risks of $\mathrm{Cd}, \mathrm{Pb}, \mathrm{Cr}, \mathrm{Ni}, \mathrm{Cu} \mathrm{Mn}, \mathrm{Zn}$, and $\mathrm{Fe}$ in soils around abandoned sites of different land use were determined. The results show variable and considerable concentrations of metals in the order of subsoil $>$ topsoil and $\mathrm{PTF}>\mathrm{FSS}>\mathrm{AMW}>\mathrm{SWD}>\mathrm{APS}$, with petroleum tank farm and fuel service station exhibiting high metal concentrations. This study revealed that $\mathrm{Cd}, \mathrm{Ni}$, and $\mathrm{Cu}$ concentrations exceeded the target limits, and the source of metals is mainly geologic and anthropogenicinduced. The risk through inhalation exposure for adults' was significantly higher than for infants, and the hazard index values for infants' exposure were higher than for adults' exposure. The ecological risk of $\mathrm{Cd}, \mathrm{Pb}$, $\mathrm{Cr}, \mathrm{Ni}$, and $\mathrm{Zn}$ was significant and falls in the contamination to pollution class. This study demonstrated the need for clean-up and restoration of soils of abandoned sites.

\section{Acknowledgments}

This work was supported and funded by the authors. Special thanks to the laboratory personnel, Department of chemistry, Delta State University, Abraka for their technical support.

\section{Conflict of interest}

The authors have no conflict of interest, hence none declared.

\section{References}

[1]. O.O. Emoyan, B.O. Peretiemo-Clarke, G.O. Tesi, W. Adjerese, E. Ohwo, Occurrence, origin and risk assessment of heavy metals measured in petroleum tank-farm impacted soils, Soil and Sediment Contamination: An International Journal 30 (2021) 384-408. DOI: 10.1080/15320383.2020.1854677

[2]. ATSDR Priority list of hazardous substances. Division of Toxicology and Human Health Sciences Agency for Toxic Substances and Disease Registry. https://www.atsdr.cdc.gov/spl/index.html

[3]. G. Baycu, D. Tolunay, H. Ozden, I. Csatari, S. Karadag, T. Agba, S.E. Rognes, An abandoned copper mining site in Cyprus and assessment of metal concentrations in plants and soil, International Journal of Phytoremediation 17 (2015) 622-631. DOI: 10.1080/15226514.2014.922929

[4]. Y. Zhu, L. Wang, X. Zhao, J. Lian, Z. Zhang, Accumulation and potential sources of heavy metals in soils of the Hetao area, Inner Mongolia, China, Pedosphere 30 (2020) 244-252. DOI: 10.1016/S1002-0160(17)60306-0

[5]. G.O. Tesi, J.O. Ojegu, S.O. Akporido, Chemical speciation and mobility of heavy metals in soils of refuse dumpsites in some urban towns in the Niger Delta, Ovidius University Annals of Chemistry 31 (2020) 66-72. DOI: 10.2478/auoc-2020-0013

[6]. O.O. Emoyan, E.E. Akporhonor, I.A. Akpoborie, Environmental Risk Assessment of River Ijana, Ekpan, Delta State, Nigeria, Journal of Chemical Speciation and Bioavailability 20 (2008) 23-32. DOI: $10.1080 / 09542299.2008 .11073770$

[7]. O.O. Emoyan, I.A. Akpoborie, E.E. Akporhonor, The oil and gas industry and the Niger Delta: Implications for the Environment, Journal of Applied Science and Environmental Management 12 (2008) 29-37. http://www.bioline.org.br/pdf?ja08046 
[8]. M.P. Thenmozhi, V. Reginald, Contamination assessment of heavy metals in the soils of an abandoned copper mine in Lasail, Northern Oman, International Journal of Environmental Studies 77 (2019) 432-446. DOI: 10.1080/00207233.2019.1644030

[9]. P. Wang, Z. Li, J. Liu, X. Bi, Y. Ning, S. Yang, X. Yang, Apportionment of sources of heavy metals to agricultural soils using isotope fingerprints and multivariate statistical analyses, Environmental Pollution 249 (2019) 208-216. DOI: 10.1016/j.envpol.2019.03.034

[10]. O. Ohwoghere-Asuma, R. Iserhein-Emekeme, K.E. Aweto, M.V. Ofomola, Geophysical Investigation of resistivity and groundwater quality in ogbe-ijoh coastal area of the western Niger Delta of Nigeria, Applied Water Science 10 (2020) 1-9. DOI:10.1007/s13201-020-1144-0

[11]. A. Concas, C. Ardau, A. Cristini, P. Zuddas, G. Cao, Mobility of heavy metals from tailings to stream waters in a mining activity contaminated site, Chemosphere 63 (2006) 244-253. DOI: 10.1016/j.chemosphere.2005.08.024

[12]. S. Muhammad, M.T. Shah, S. Khan, Heavy metal concentrations in soil and wild plants growing around $\mathrm{Pb}-\mathrm{Zn}$ sulfide terrain in the Kohistan region, northern Pakistan, Microchemical Journal 99 (2011) 67-75. DOI: 10.1016/j.microc.2011.03.012

[13]. L. Vilavert, M. Nadal, M. Schuhmacher, J.L. Domingo, Concentrations of metals in soils in the neighborhood of a hazardous waste incinerator: Assessment of the temporal trends, Biological Trace Element Research 149 (2012) 435-442. DOI: 10.1007/s12011-012-9441-6

[14]. S.K. Reza, U. Baruah, D. Sarkar, Hazard assessment of heavy metal contamination by the paper industry, north-eastern India, International Journal of Environmental Studies 70 (2013) 23-32. DOI: $10.1080 / 00207233.2012 .746810$

[15]. U.B. Onyedikachi, D.C. Belonwu, M.O. Wegwu, Human health risk assessment of heavy metals in soils and commonly consumed food crops from quarry sites located at Isiagwu, Ebonyi State, Ovidius University Annals of Chemistry 29 (2018) 2-24. DOI: 10.2478/auoc-2018-0002

[16]. P. Dinake, R. Kelebemang, N. Sehube, O. Kamwi, M. Laetsang, Quantitative assessment of environmental risk from lead pollution of shooting range soils, Chemical Speciation and Bioavailability 30 (2018) 76-85. DOI: 10.1080/09542299.2018.1507689

[17]. L. Sun, D. Guo, K. Liu, H. Meng, Y. Zheng, F. Yuan, G. Zhu, Levels, sources, and spatial distribution of heavy metals in soils from a typical coal industrial city of Tangshan, China, Catena 175 (2019) 101-109. DOI: 10.1016/j.catena.2018.12.014

[18]. R.Q. Macasieb, C.R. Orozco, A.C. Resurreccion, Heavy metal contamination assessment and source apportionment analysis using multivariate methods in surface sediments of mining-impacted rivers in
Benguet, International Journal of Environmental Studies 78 (2021) 283-300. DOI: 10.1080/00207233.2020.1802953

[19]. K.E. Aweto, Down-hole Geophysical investigation of Lithological strata and water quality in the Deltaic plain deposits and Mangrove Swamps of Niger Delta, Nigeria Journal of Pure and Applied Sciences 31 (2018) 3204 - 3211. DOI: $10.6084 / \mathrm{m} 9$. figshare. 12317312

[20]. O.O. Emoyan, B.O. Peretiemo-Clarke, G.O. Tesi, E. Ohwo, Occurrence, origin, ecological and human health risks of organochlorine pesticides in soils from selected urban, suburban and rural storm water reservoirs, Soil and Sediment Contamination: An International Journal 30 (2022) 152-175. DOI: 10.1080/15320383.2021.1913993

[21]. C.M.A. Iwegbue, G. Obi, O.O. Emoyan, E.W. Odali, F.E. Egobueze, G.O. Tesi, G.E. Nwajei, B.C. Martincigh, Characterization of metals in indoor dusts from electronic workshops, cybercafés and offices in southern Nigeria: Implications for on-site human exposure, Ecotoxicology and Environmental Safety 159 (2018) 342-353. DOI: $10.1177 / 1420326$ X19876007

[22]. USEPA, Regional screening levels (RSL) summary tables. https://www.epa.gov/risk/regional-screeninglevels-rsls-generic-tables (2020) (accessed on 23 January 2021).

[23]. O.O. Emoyan, Quantification and cancer risk evaluation of polycyclic aromatic hydrocarbons in soil around selected telecom masts in Delta state Nigeria, Egyptian Journal of Chemistry 63 (2020) 433-448. DOI: 10.21608/ejchem.2019.17620.2081

[24]. DPR-EGASPIN, Department of Petroleum Resources-Environmental guidelines and standards for the petroleum industry in Nigeria (revised edition). Ministry of Petroleum and Natural Resources, Abuja, Nigeria (2002) 320. https://ngfcp.dpr.gov.ng/media/1066/dprsegaspin-2002

[25]. G. Muller, Index of geoaccumulation in sediments of the Rhine River, GeoJournal 2 (1969) 108-118. https://www.mendeley.com/catalogue/b9c6dcd66549-3c0e-bc7f-cef4af95e8bd/

[26]. C. Reimann, P. de Caritat, Intrinsic flaws of element enrichment factor (EFs) in environmental geochemistry, Environmental Science and Technology 34 (2000) 5084-5091. DOI: $10.1021 / \mathrm{es} 0013390$

[27]. K. Loska, D. Wiechula, Application of principle components analysis for the estimation of source of heavy metal contamination in surface sediments from the Rybnik Reservoir, Chemosphere 51 (2003) 723-733. DOI: 10.1016/s00456535(03)00187-5

[28]. K.K. Turekian, K.H. Wedepohl, Distribution of the elements in some major units of earth crust, Bulletin of America Geological Society 72 (1961) 175-192. DOI: $10.1130 / 0016$ 7606(1961)72[175:DOTEIS]2.0.CO;2 
[29]. L. Hakanson, An ecological risk index for aquatic pollution control: A sedimentological approach, Water Research 14 (1980) 975-1001. DOI: 10.1016/0043-1354(80)90143-8

[30]. E.R. Long, D.D. MacDonald, Recommended uses of empirically derived, sediment quality guidelines for marine and estuarine ecosystems, Human and Ecological Risk Assessment 4 (2010) 1019-1039. DOI: $10.1080 / 10807039891284956$

[31]. E.R. Long, D.D. MacDonald, S.L. Smith, F.D. Calder, Incidence of adverse biological effects within ranges of chemical concentrations in marine and estuarine sediments, Environment Management 19 (1995) 81-97. DOI: 10.1007/BF02472006

[32]. P.M. Salas, C.H. Sujatha, C.H. Ratheesh, C.S. Kumar, E. Cheriyan, Heavy metal distribution and contamination status in the sedimentary environment of Cochin estuary, Marine Pollution Bulletin 119 (2017) 191-203. DOI: 10.1016/j.marpolbul.2017.04.018

[33]. A. Krishnan, C.H. Sujatha, Structural characterization of fulvic acids and their impact in the agricultural area of Palakkad, Kerala, India. Environmental Forensics 21 (2020) 132-144. DOI: 10.1080/15275922.2020.1728431

[34]. O.O. Emoyan, C.C. Ikechukwu, G.O. Tesi, Occurrence and sources of aliphatic hydrocarbons in anthropogenic impacted soils from petroleum tank-farms in the Niger Delta, Nigeria, Ovidius University Annals of Chemistry 31 (2020) 66-72. DOI: $10.2478 /$ auoc-2020-0022

[35]. O.O. Emoyan, G.O. Tesi, E. Ohwo, C. Olisah, S.U. Oghoje, Polybrominated diphenyl ethers concentrations in metals and plastics scrap impacted soils: Pollution load, sources, ecological, and onsite human health implications, Environmental Forensics (2021) DOI: 10.1080/15275922.2021.2006367

[36]. N. Basavaiaha, R.D. Mohiteb, P.U. Singarec, A.V.R Reddyd, R.K. Singhald, U. Blahae, Vertical distribution, composition profiles, sources and toxicity assessment of PAH residues in the reclaimed mud flat sediments from the adjacent Thane Creek of Mumbai, Marine Pollution Bulletin $118 \quad$ (2017) 112-124. DOI: 10.1016/j.marpolbul.2017.02.049

[37]. O.O. Emoyan, G.O. Tesi, E. Ohwo, E.W. Odali, Quantification, sources, and associated risks of 16priority polycyclic aromatic hydrocarbons from selected land-use impacted soils, Ovidius University Annals of Chemistry 32 (2021) 53-62. DOI: $10.2478 /$ auoc-2021-0008

[38].F.A. Vega, E.F. Covelo, M.L. Andrade, Competitive sorption and desorption of heavy metals in mine soils: Influence of mine soil characteristics, Journal of Colloid and Interface Science 298 (2006) 582-592. DOI: 10.1016/j.jcis.2006.01.012

[39]. O.O. Emoyan, S.O. Akporido, P.O. Agbaire, Effects of soil $\mathrm{pH}$, total organic carbon and texture on fate of polycyclic aromatic hydrocarbons
(PAHs) in soils, Global NEST Journal 20 (2018) 181-187. DOI: 10.30955/gnj.002277

[40]. M. Radziemska, J. Fronczyk, Level and Contamination Assessment of Soil along an Expressway in an Ecologically Valuable Area in Central Poland, International Journal Environmental Research and Public Health 12 (2015) 13372-13387. DOI: 10.3390/ijerph121013372

[41]. O.F. Olorundare, K.O. Ipinmoroti, A.V. Popoola, J.G. Ayenimo, Anthropogenic Influence on Selected Heavy Metal Contamination of Urban Soils of Akure City, Nigeria, Soil and Sediment Contamination: An International Journal 20 (2011) 509-524. DOI: 10.1080/15320383.2011.587041

[42]. B. Hu, X. Jia，J. Hu，D. Xu，F. Xia, Y. Li, Assessment of heavy metal pollution and health risks in the soil-plant-human system in the Yangtze river delta, China, International Journal of Environmental Research and Public Health 14 (2017) 1042-1060. DOI: 10.3390/ijerph14091042

[43]. O.H. Adedeji, O.O. Olayinka, O.O. Tope-Ajayi, Spatial distribution and health risk assessment of soil pollution by heavy metals in Ijebu-Ode, Nigeria, Journal of Health and Pollution 9 (2019) 90601. DOI: 10.5696/2156-9614-9.22.190601

[44]. T.A. Delvalls, J.M. Forja, A. GomezParra, Seasonality of contamination, toxicity, and quality values in sediments from littoral ecosystems in Gulf of Cadiz (SW Spain), Chemosphere 46 (2002) 1033-1043. DOI: 10.1016/s0045-6535(01)00176-x

[45]. P. Khodadoust, K.R. Reddy, K. Maturi, Removal of nickel and phenanthrene from kaolin soil using different extractants, Environmental Engineering Science 21 (2004) 691-704. DOI: 10.1089/ees.2004.21.691

[46]. M. Jaishankar, T. Tseten, N. Anbalagan, B.B. Mathew, K.N. Beeregowda, Toxicity, mechanism and health effects of some heavy metals, Interdisciplinary Toxicology 7 (2014) 60-72. DOI: 10.2478/intox-2014-0009

[47]. U. Najeeb, W. Ahmad, M.H. Zia, Z. Malik, W. Zhou, Enhancing the lead phytostabilization in wetland plant Juncus effusus L. through somaclonal manipulation and EDTA enrichment, Arabic Journal of Chemistry 102 (2017) S3310S3317. DOI: 10.1016/j.arabjc.2014.01.009

[48]. M. Xu, Y. Cui, J. Beiyuan, X. Wang, C. Duan, L. Fang, Heavy metal pollution increases soil microbial carbon limitation: Evidence from ecological enzyme stoichiometry, Soil Ecology Letters 3 (2021) 230-241. DOI: 10.1007/s42832021-0094-2

[49]. H. Qian, J. Chen, K.W.F. Howard, Assessing groundwater pollution and potential remediation processes in a multi-layer aquifer system, Environmental Pollution 263:A (2020) 114669. DOI: 10.1016/j.envpol.2020.114669

[50]. J. Chen, H. Qian, Y. Gao, H. Wang, M. Zhang, Insights into hydrological and hydrochemical processes in response to water replenishment for lakes in arid regions, Journal of Hydrology 581 
(2020) $124386 . \quad$ DOI:

10.1016/j.jhydrol.2019.124386

[51]. J. Chen, H. Wu, H. Qian, Y. Gao, Assessing nitrate and fluoride contaminants in drinking water and their health risk of rural residents living in a semiarid region of Northwest China, Exposure and Health 9 (2017) 183-195. DOI: 10.1007/s12403016-0231-9

[52]. N.S. Kasimov, N.Y. Kosheleva, O.A. Samonova, Mobile forms of heavy metals in soils of middle Volga forest-steppe: Experience of multivariate regression analysis, Eurasian Soil Science 28 (1996) 47-61.

[53]. Y. Fujikawa, M. Fukui, A. Kudo, Vertical distributions of trace metals in natural soil horizons from Japan. Part 1. Effect of soil types, Water, Air, and Soil Pollution 124 (2000) 1-21. DOI: 10.1023/A:1005120204500

[54]. R.A. Sutherland, F.M.G. Tack, A.D. Ziegler, Road-deposited sediments in an urban environment: The first look at sequentially extracted element loads in grain size fractions, Journal of Hazard Matter 225-226 (2012) 54-62. DOI: 10.1016/j.jhazmat.2012.04.066

[55]. K.F. Ho, S.C. Lee, H. Guo, W.Y. Tsai, Seasonal and diurnal variations of volatile organic compounds (VOCs) in the atmosphere of Hong Kong, Science of the Total Environment 322 (2004) 155-166. DOI: 10.1016/j.scitotenv.2003.10.004

[56]. M. Gaur, R. Singh, A. Shukla, Variability in the levels of BTEX at a pollution hotspot in New Delhi, India, Journal of Environmental Protection $7 \quad$ (2016) 1245-1258. DOI: 10.4236/jep.2016.710110

[57]. O.O. Emoyan, B.O. Peretiemo-Clarke, G.O. Tesi, E. Ohwo, W. Adjerese, Concentrations, sources, and associated risks of polychlorinated biphenyls measured in soil profiles from selected telecommasts in the Niger Delta, Nigeria, Soil and Sediment Contamination: An International Journal (2021). DOI: 10.1080/15320383.2021.1937934
[58]. O.O. Emoyan, O.O. Ejecha, G.O. Tesi, Concentration assessment and source evaluation of 16 priority polycyclic aromatic hydrocarbons in soils from selected vehicle-parks in southern Nigeria, Scientific African 7 (2020) e00296. DOI: 10.1016/j.sciaf.2020.e00296

[59]. C.M.A. Iwegbue, D. Odogbor, F.E. Egobueze, O.O. Emoyan, G.O. Tesi, Polycyclic aromatic hydrocarbons in smoked Ethmalosa fimbriata and Gymnarchus niloticus from selected fish markets in the Niger Delta, Nigeria, Polycyclic Aromatic Compounds 40 (2020) 1367-1380. DOI: 10.1080/10406638.2018.1550794

[60]. C.M.A. Iwegbue, G.O. Tesi, L.C. Overah, O.O. Emoyan, G.E. Nwajei, B.C. Martincigh, Effects of flooding on the sources, spatiotemporal characteristics and human health risks of polycyclic aromatic hydrocarbons in floodplain soils of the lower parts of the River Niger, Nigeria, Polycyclic Aromatic Compounds 40 (2020) 22844. DOI: $10.1080 / 10406638.2017 .1403329$

[61]. O.O. Emoyan, Occurrence and exposure risk of mono-aromatic hydrocarbons in selected petroleum product jetty impacted soils from the Niger Delta, Nigeria, Egyptian Journal of Chemistry 64 (2021) 2567-2578. DOI: 10.21608/EJCHEM.2021.40450.2821

[62]. O.O. Emoyan, P.O. Agbaire, E. Ohwo, G.O. Tesi, Priority mono-aromatics measured in anthropogenic impacted soils from Delta, Nigeria: concentrations, origin, and human health risk, Environmental Forensics (2021). DOI: 10.1080/15275922.2021.1892880

[63]. E. Akporhonor, O.O. Emoyan, P.O. Agbaire, Concentrations, origin, and human health risk of polycyclic aromatic hydrocarbons in anthropogenic impacted soils of the Niger Delta, Nigeria, Environmental Forensics (2021). DOI: 10.1080/15275922.2021.1892877

Received: 26.01 .2022

Received in revised form: 16.02.2022

Accepted: 18.02 .2022 